\title{
PRECARIOUS LIFE, JUDGMENT AND A STORY OF A STORK
}

\author{
by Karin van Marle*
}

\begin{abstract}
In this short reflection I focus on a number of notions and issues that for me are of value and relevance within the time and space that we find ourselves at present. I consider what meaning a life in the university could have and what kind of space the university should be to make this meaning and life possible.
\end{abstract}

\section{Precarious life}

Judith Butler in her work Precarious life. The powers of mourning and violence published in the aftermath of September 11 argues that the event raised the "question ... as to what form political reflection and deliberation ought to take if we take injurability and aggression as two points of departure for political life."1 After another year filled with events and actions that showed aggressions and caused injury on global, national and sometimes on a local level very close to home we might consider exactly the question invoked by Butler. She hopes for the 'chance to imagine a world' with less violence and where interdependency is deemed necessary and foundational to all relations.

A theme coming to the fore in the first essay of Precarious life is the rise of censorship and anti-intellectualism in the US after September 11.2 For students and academics these issues should be of a big concern. To what extent are the media, artists, authors and closer to home students and academics free to express their views even if not censored in strict legal sense, are we silenced, disencouraged, dissuaded to speak up and speak out? Maybe even a bigger concern is not only the absence of intellectual engagement, conversation and discussion at the university but the active antiintellectualism that comes in many guises.

* Karin van Marle served the University of Pretoria, Faculty of Law, Department of Jurisprudence from 1 February 1999 - 31 January 2019. She will continue her service to legal scholarship and academia at the University of the Free State from 1 February 2019.

1 J Butler Precarious life. The powers of mourning and violence (2004) xii.

2 As above 1-18. 


\section{The banality of evil and judgment}

Hannah Arendt in her report on the trial of the Nazi, Adolf Eichman used the term the 'banality of evil' to describe him. ${ }^{3}$ As Young-Bruehl notes, Arendt regarded Eichman as a 'superficial person, thoroughly conformist to his thoroughly banal society, with no independent sense of responsibility.' 4 The only thing that motivated Eichman was his own ambition to be promoted. Arendt perceived him as being 'thoughtless' and by this she means that he didn't have 'common sense or the ability to think.' Apparently Eichman could recite moral rules, even the categorical imperative as developed by Immanuel Kant, but he couldn't think for himself. Later in her life Arendt reflected on the notion of judgement, the feature so lacking in Eichman.

Judgement of course as the ability to think and act responsibly is of utmost importance to all people, but maybe in particular to those in legal scholarship. Arendt believed that judgment should take place in relationship with others. Following Kant's notion of aesthetic judgement she believed that when one judges one imagines the perspectives of as many others as possible and enters into a conversation with them. Young-Bruehl explains that what is needed in judgement is 'an enlarged mentality' a 'communicative experience' that could allow one to 'transcend' one's own subjectivity and reach 'common sense." 6

... judging presupposes being able to see what the world is like from another's perspective. This does not mean adopting another's judgment or agreeing with another's opinion, or even emphathizing with another's experience or reading his or her mind. It simple means using your imagination to see things from another's standpoint. ${ }^{7}$

Arendt noted that: 'The more people's positions I can make present in my thought and hence take into account in my judgments, the more representative [my judgment] will be.,8

Following form the above I believe the university and the faculty of law should be a place that encourages this kind of judgment meaning a place where a plurality of perspectives could be considered. Thinking should be central to all teaching and learning and research in order not to allow more Eichmans into the world.

The $P S L R$ received many submissions this year covering indeed a plurality of perspectives and topics including medical law, adultery,

3 H Arendt Eichman in Jerusalem. A report on the banality of evil (1963).

4 E Young-Bruehl Why Arendt matters (2006) 3.

5 As above.

6 As above 166.

7 As above.

8 Arendt 'Some questions of moral philosophy' in J Kohn (ed) Responsibility and judgment (2003) 49 as quoted by Young-Bruehl n3 166. 
prostitution, tax, socio-economic rights and many more. Articles were submitted by students from within and outside the University of Pretoria and include submissions by undergraduates and postgraduates. We are honoured to publish also an article by a visually impaired student this year.

\section{Taking stock}

Coming to year end we often take stock of what we've been doing during a year, what aims or milestones have been achieved and we pose those existential questions of who are we and where are we going? Below I share briefly some of the thoughts that I shared in a seminar hosted by Law House related to their theme of the year, Year of the woman. I started by recalling the following story as told by Danish author Karen Blixen:

A man, who lived by a pond, was awakened one night by a great noise. He went out into the night and headed for the pond, but in the darkness, running up and down, back and forth, guided only by the noise, he stumbled and fell repeatedly. At last, he found a leak in the dike, from which water and fish were escaping. He set to work plugging the leak and only when he had finished went back to bed. The next morning, looking out of the window, he saw with surprise that his footprints had traced the figure of a stork on the ground. ${ }^{9}$

Adriana Cavarero responds to the story by asking if one will be able to see a stork at the end of one's life - is there a design that has a meaning to be recognised? Following Hannah Arendt, Cavarero insists on the importance of who someone is rather than what someone is. ${ }^{10}$ Who someone is can only be revealed by stories. The tendency in philosophy and, of course, law is to give prominence to the what rather than the who. In my work over many years I have attempted to think about and suggest a jurisprudence that strives to be attentive to the who, that could be open to the possibility of interconnectedness and relations. As Cavarero states, the extent to which a design, meaning could be recognised is not something that can be foreseen, projected or controlled. The man in the story did not intend anything more than to find the reason for the noise and fix it - the design, meaning at the end, the trace of a stork, happened without any preconceived plan, design or project. What stands out in Blixen's story and Cavarero's engagement with it, is the emphasis on being attentive to the story of who someone is, and the possibility of meaning coming to the fore, interconnection and relationality recognised.

9 A Cavarero Relating narratives. Storytelling and selfhood (2000) 1.

10 As above 2. 
For me after more than three decades at the university initially as a student and later as lecturer it is interesting to stop and wonder for a moment about the picture/image/design that has been, and is being, and will be traced. What I really appreciate about Blixen's story is that there is nothing grand or monumental about it, nothing is lasting, when the sun rises the design created by the footsteps will disappear, but what makes it complex and therefore interesting is that at the same time there is not nothing ...

During my talk to Law House I shared some observations in line with their theme, 'Women in academia' but my sense is that it applies over a broad spectrum. I recall only two here. Firstly the idea that a life at the university, the life of the mind, intellectual endeavours are beyond and totally different from the steps (promotion/ achievements) that are often held to be what should be strived for. To connect with the story of the stork mentioned it is who one is and not what one is that counts.

Secondly, what kept me sane (more or less) but also what kept me here at UP for so many years was the extent to which different places and spaces within the university became a home for me. And of course as a feminist I know that the home is often the most unsafe, violent and unhappy place for a woman - at the same time I believe that a home, symbolic or material, can be a source of strength and imagination and hope - a place or space from where one can think and read and write and speak.

Let me end this reflection by making reference to a recent article in which I reflect on the neoliberal university. ${ }^{11}$ The main objective of the article by drawing on work on atmosphere, affect and complexity, is to reflect on the way in which a certain neoliberal logic and rationality have become a kind of common-sense - but of course exactly not in the Arendtian understanding of common-sense reached after taking into account a plurality of perspectives - at the university. I contemplate the possibility of a different aesthetic: one that acknowledges bodily-presence, sensory experiences, complexity and the need to slow down, to step aside from counting, competitiveness and suffocation. This kind of aesthetic could influence the idea of the university as a public space, may make it a space of inhabitance and could offer an alternative to present day campuses where one is allowed only if biometrics are captured; where interdicts reign, preventing any form of protest or dissent. My sense is that a different aesthetic could transform the curriculum, disclose opportunities for ideas and reflection and produce more than functionaries to further the machine. Crucially, it will enhance the

11 K Van Marle 'Life is not simply fact': Aesthetics, atmosphere and the neoliberal university' (2018) Law and Critique. 
world outside the university if graduates could contribute to a lifeworld that is not one of mere instrumentality.

Of course when one thinks and writes about the university it is important to note both the Western and masculine nature of the university. In the words of Mahmood Mandani '[most universities] are local instantiations of a dominant academic model based on a Eurocentric epistemic canon.' 12 The implication of a Western canon is that it values only Western/ masculine notions of the truth and rejects all other forms of knowledge. An important feature of many Western epistemic traditions is their reliance on a certain division between 'mind and world', 'reason and nature', and on a detachment between the 'knower' and the 'known'. This point doesn't speak only to epistemology, ways of knowing, but also ontology, ways of being. Achille Mbembe notes that the main problem of this form of epistemology and ontology is that they become hegemonic and do not acknowledge other ways of understanding, being in and inhabiting the world. ${ }^{13}$

I would like to draw on Mbembe's invocation in the preface to the African edition of On the postcolony of the words of W.E. Du Bois that 'Life is not simply fact.' 14 He highlights the role that African music played in the writing of the book. He says that the traditions of the African novel and late 20th century African music taught him 'that to think is to experiment ... To think ... is also to recover and rescue the figurative power of allegory as it applies to specific realms of human experience'. ${ }^{15}$ Lastly he says that to think is 'to embark on a voyage of the mind.' He comments also on critical thinking, saying that it means 'to work with the fault lines, to feel the chaotic touch of our senses, to bring the compositional logics of our world to language., 16 He further describes critique as 'witnessing' and as 'endless vigilance, interrogation and anticipation.' Echoing the words of Du Bois that 'life is not simply fact' Mbembe declared the role that art and music and literature play in disclosing multiple aspects of life that 'objective knowledge' couldn't reveal. ${ }^{17}$

Like the man running up and down to fix his pipe this reflection is not designed to leave you with a worked out message or lesson. But it is also not mere words stringed together. Take a moment and connect the dots between Butler's thoughts on politics in the time of aggression and injury; anti-intellectualism and censorship as response

12 M Mamdani 'Between the public intellectual and the scholar: decolonization and some post-independence initiatives in African higher education' (2016) Inter-Asia Cultural Studies 17 68-83.

13 A Mbembe 'Decolonizing the university: New directions (2016) Arts \& Humanities in Higher Education 15 29-45.

14 A Mbembe On the postcolony (2015) xiii.

15 As above Xv.

16 As above.

17 As above xvi. 
to complexity; and Arendt's description of Eichman as thoughtless, banal, a follower of rules to serve his own ambition. Go further and think about the notion of judgment as something that occurs by taking into account a plurality of perspectives and positions. Bring all of this to the university, but also to your life design. Are we open for Du Bois's insight that life is about much more than facts; ethics and morality about much more than a mere following of rules; humans about much more than what we do, and what we are, but rather who we are? Do we honour the interdependence of humans, fundamental connection and relationality?

I have had the privilege to work with a team of editors committed to the continuance of the university and the faculty of law as an intellectual space where the pursuit of ideas is encouraged and celebrated. We had numerous meetings where we deliberated and imagined a plurality of perspectives to guide us in making decisions. I want to thank everyone of you, Primrose ER Kurasha; Agnes Matasane; , Vaughn Rajah; Kirsten Swanepoel and Jurgen Zwecker for your dedication to the journal and for keeping the intellectual life of the faculty going in this way. A special word of thanks to Jurgen who in a calm and wise manner kept things together and worked hard to finalise the volume. A thanks also to Adebayo Okeowo for the care he took in putting together the back and front pages of the journal. Thanks also to Lizette Hermann for her enthusiastic support and technical savvy. To all the authors who submitted articles and to those whose articles have been taken up in the journal in this volume - congratulations to all of you. All the best to the 2019 editorial board and hereby an invitation to all of you reading this edition to write and to submit to the journal. Happy writing! 